\section{TEMPERATURE OF THE HUMAN BODY AFTER DEATH.}

BY W. C. MACLEAN, M.D.,

DEFUTY INSPECTOR GENERAL, AND PROTESSOR OF MILITARY MEDICINIS,

Or a recent trial for murder, a medical witness gave very positive evidence as to the number of hours that had elapsed since death, grounding his opinion on the fact that the body still feit warm to the hand placed on the abdomen. If I remenber well, this gentleman "explained" the high temperature of the abdomen by stating that the woman was pregnant. I think it was a very general impression in the profession that no facts exist on which so confident an opinion could be grounded. Be this, however, as it may, I place the following on record as a contribution to our knowledge on this not un. important point :-

Private John C-__, 22ud Regiment, aged twenty four. He was invalided bome fiom Malta suffering from purpura, which followed an attack of continued fever, prohably typhoil, as it was said to have been "complicated with diarrhoea." "I"his young wan had a syphilitio history, and his habits were ex. tremely intemperate. He was admitted into the Medical Division of Fort Pitt Hospital ou the $19 \mathrm{ch}$ of Cetober, 1862. He was then much emaciated and very weak, with slight but rather frequent cough without expectoration; the lower ex. tremities and abdomen were covered with purpuric patches; the liver was enlarged, the abrlonon tympanitie, with enlargement of supericial abdominal veins, and there was serous effu sion in to the abdominal cavity.

This man had repeated attacks of epistaxis, requiring the use of the plug in the posterior nares on two occasions, and repeatedly passed blood by stool. Nevertheless, after a time, under careful muagement, his condition improved, he gained flesh, the bloody dischirges ceased, and his general health advanced. Unfortunately, he was seized with double pleurisy, with enormolis effusion into the right side, which terminated fatally on the 27 th of December, at six A.M. At half-past twelve P.M., Staff Assistant-Surgeon Woods and myself took the temperature of his body, which lay on a grating on the floor of an extremely cold deadhouse, where the body was covered with a sheet, and had remained for six hours and a half after death. The instrument used was a delicate thermometer, made by Negretti and $Z$ ambra, for taking the temperature in disease. At the time of the experiment it stood at $52^{\circ}$. Placed in the axilla, it rose to $66^{\circ}$; in the month, to $63^{\circ}$. On the chest and abdomen it stood at $65^{\circ}$.

Army Medical School, Fort Pitt, Dec. 1S62.

OAS

\section{ON A CASE}

OF

\section{POISONING BY A GRAIN OF ACETATE OF MORPHIA IN A CHILD.}

By L. WINTERBOTHAM, EsQ., M.R.C.S., SURGRON TO THE CHELTENHAMF GENERAL HOSPITAL A.ND DISPEMSARX.

THE following case of recovery in so young a child from the effects of a grain of acetate of morphia taken in a soluble state, and retained undisturbed in the sfstem for two hours and a half, is, perhaps, worthy of record :-

S. I- aged two years and three months, at nine o'clock on the morning of the $13 \mathrm{th}$ of Nurember last, obtained possession of a phial, containing a grain of acetate of morphia in solution in an ounce of oxymel of squills, (a medicine of which her mother was taking a teaspoonful at bedtime,) and swallowed the whole of its contents.

At half past eleven, when I first saw the child, no vomiting had occurred, althougb, in addition to the oxymel of squills taken with the poison, she had had, in teaspoonful doses, half an ounce of ipecacuanba wine sent by a chemist, to whom application had been made. I found the child with cold skin, pale face, blue lips, slow weak pulse, and pupils contracted to a point; totally unable to stand, and with difficulty aroused to consciousness enough to express, in childish gestures, its intense desire to be left alone to sleep. Finding that the child still attempted to swallow when a moistened spoon was rubbed against its lips, I administered two grains of sulphate of zinc in some coffee, more with the hope of rousing the child with the effort of vomiting than with the intention of emptying the stomach of the poison, which 1 believe had been by this time absorbed into the system. In a few minutes the dose was repeated, and on irritating the fauces with the fin_er, free vomit. ing was induced The emetic acted about six times, strong coffee being freely given during each interval.

At half-past twelve the emetic effect of the zinc had ceased, and the child's state had decidedly improved. She swallowed readily, and could stand for a few seconds unaided, though she was with difficulty kept awake by friends and neighbours, who relieved each other every few minutes in leading her about in the open air, and giving her as much strong coffee as she could be got to swallow.

At half-past two the child was brought to my house. She was icy cold, with an almost imperceptible pulse. She soon rallied, however, under the influence of a warm room and a teaspoonful or so of hot wine-and-water, when a great improvement was manifest. The pupils were less contracted, though still immovable. She was less drowsy, and could walk a few steps with a tottering gait. She was ordered to be kept thoroughly awake, and to continue taking coffee.

At balf-past eight the effects of the poison were wearing off. The pupils were less contiacted, and the irides answered slowly to the stimulus of a lighted candle. She could walk unaided, and had just passed urine for the first time since taking the poison. The stupor had given place to extreme restlessness and irritability of manner, and her teeth were chattering with cold. She took some hot egg and milk, with a little wine, and at nine o'clock (twelve hours after taking the poison) she was allowed to sleep, $\mathrm{Mr}$. Bubb (in my absence) undertaking to see her in an hour's time, and again during the night. Under Mr. Bubb's directions she was allowed to sleep alternate half hours during the night.

At half-past nine, on the 14th, I found her free from any trace of opium poisoning, but in an extreme state of restlessness, bordering on delirium tremens. I got her undressed and placed warmly in bed, (she had been in her clothes in her mother's arms during the night, ) and ordered her small doses of chloric ether and ammonia every few hours. After the first dose she fell soundly asleep, and slept all through the day and following uight, only being awakened to take her food and medicine; and on the morning of the 15 th she woike in her usual health, the bowels acting of their own accord for the first time since taking the poison.

Chelteuham, Dec. 1862.

\section{I a thlitrot}

OF THE PRACTICE OF

\section{MEDICINE AND SURGERY IN THE}

\section{HOSPITALS OF LONDON.}

Nalla est alia pro certo noscendi via, nisi quam plurimas et morborum et dissectionum historias, tam aliorum proprias, collectas habere et inter se comparare.-Morgagn.' De Sed. et Caus. Morb., lib.14. Procmium.

\section{GUY'S HOSPITAL.}

FISTULA BETWEEN THE GALL-BLADDER AND COLON; PHTHISIS AND BRIGIT'S DISEASE; DIPHTHERITIC EXUDATION IN THE ILEUM ; FATAL RESULT.

(Under the care of Dr. BARLow.)

OUR present series comprises some rare and strikingly interesting examples of disease in which a portion of the intestinal tube was the subject of a fistulous communication either with some other organ, such as the urinary or gall bladder, or with the external parts; in the latter instance forming a preternatural anus. Unusually dangerous as such solutions of continuity are, not only was life saved in several cases, but a cure of the fistula was effected without any apparent inconvenience to the subject of it. Each case has distinctive pecu. liarities; but in all peritoneal inflammation was the chief 